\title{
Legitimate Authority and the Ethics of War: A Map of the Terrain
}

\section{Jonathan Parry*}

\begin{abstract}
Despite a recent explosion of interest in the ethics of armed conflict, the traditional just war criterion that war be waged by a "legitimate authority" has received less attention than other components of the theory. Moreover, of those theorists who have addressed the criterion, many are deeply skeptical about its moral significance. This article aims to add some clarity and precision to the authority criterion and to debates surrounding it, and to suggest that this skepticism may be too quick. First, it provides an analysis of the authority criterion, and argues there are (at least) two distinct moral claims associated with the criterion, requiring separate evaluation. Second, it outlines an increasingly influential "reductivist" approach to just war theory, and explains how it grounds powerful objections to the authority criterion. Third, and in response, it sketches the most promising strategies for providing a (qualified) defense of authority, and the further questions and complications they raise. Importantly, these strategies aim to rehabilitate the authority criterion from within a broadly reductivist view.
\end{abstract}

Despite an explosion of interest in the ethics of war over the past two decades, the traditional just war criterion that a war must be waged by a "legitimate authority" has received less attention than other standard components of the theory. This contemporary downgrading should be surprising. The founding fathers of the just war tradition, such as Augustine and Aquinas, gave the authority criterion pride of place. Within the medieval landscape of diverse, overlapping, and hierarchical forms of political organization, the key question for these thinkers was which kinds of entities had the right to make war. ${ }^{1}$ Given that today's conflicts are fought by a wide range of "irregular" belligerents, thereby challenging the idea of war as a relation between states, one would have expected the authority criterion-which deals with the distinct question of "who" is engaging in violence-to be at the center of debates.

Fortunately, the tide does seem to be turning, with several theorists recently focusing their attention on the ethics of nonstate violence, and on the authority question in particular. ${ }^{2}$

\footnotetext{
* I would like to thank Christopher Finlay, Pål Wrange, three anonymous reviewers, and the journal editors for their helpful comments on an earlier draft.
} 
However, it is not always clear in these discussions what the precise object of assessment is. Whereas other traditional just war criteria, such as just cause and proportionality, have clear analogues in ordinary interpersonal morality, the authority criterion can appear rather mysterious. Nor is it clear how we should go about making sense of this notion within a modern secular ethics that views the individual as the ultimate unit of moral concern and evaluation. Indeed, as we shall see, many conclude that no such reconciliation is possible, and that the criterion should be abandoned.

My chief aims in this article are to add some clarity and precision to the authority criterion and to the debates surrounding it, and to suggest that this skepticism may be too quick. The paper proceeds in three stages. First, I will provide an analysis of the criterion and the role that it plays within just war theorizing. Drawing on previous work, I will suggest that there are at least two distinct kinds of moral claim associated with the authority criterion, which call for separate evaluation. Second, I will outline a powerful challenge to the idea that authority plays any significant role within the ethics of war. The challenge is posed by an increasingly influential "reductivist" approach to just war theory, the central tenet of which is that the morality of war is constituted solely by the moral principles that govern violence between private individuals. Since, by hypothesis, those principles give no special role to considerations of authority, reductivists hold that the criterion should be jettisoned. Third, and in response, I will sketch what I take to be the most promising strategies for providing a (qualified) defense of the authority criterion. Importantly, these do not deny the central reductivist claim that war is morally continuous with private action. Instead, I aim to show how we might rehabilitate the authority criterion within a broadly reductivist view, and to highlight the further questions and complications raised by taking this course.

\section{Two COnCEPTions of Authority}


Before assessing the reductivist challenge, it is helpful to distinguish two questions that we can ask about the authority criterion. First, what normative consequences are meant to follow from the possession or non-possession of war-making authority? What moral difference should a belligerent's authority or lack thereof make? Second, what relevant properties must an entity have in order to possess war-making authority, understood as the ability to trigger the aforementioned normative consequences? The first question has priority over the second: We cannot determine which entities (if any) have authority until we know what having authority consists of.

As noted, the authority criterion is open to at least two distinct interpretations in terms of its normative consequences. ${ }^{3}$ On the standard interpretation, which I will call the "restrictive authority criterion," familiar from any textbook on just war theory, the authority criterion functions in the same way as all other jus ad bellum criteria, by imposing a necessary condition for war to be morally permissible. To have authority means that one's belligerent activities are eligible for justification. In other words, for a war to be morally justified, it must be fought by an entity that possesses a certain set of properties. Wars fought by entities lacking such properties are unjustified.

While this conception dominates, there is another plausible interpretation, which I will call the "permissive authority criterion." This departs from the standard view in two respects. First, it treats the criterion as having an essentially permissive function. Second, this permissiveness manifests itself primarily at the level of individual conduct in war (jus in bello), rather than at the ad bellum level. ${ }^{4}$ In other words, if an individual participates in armed conflict on behalf of an entity that possesses a certain set of properties, their conduct is subject to more permissive moral norms. Individuals who use violence on behalf of entities that lack those properties remain subject to the ordinary constraints of interpersonal morality. 
To motivate this interpretation, compare the norms of conduct commonly accepted in the context of war with those contained in "ordinary" interpersonal morality. A common theme that runs through the just war tradition is the idea that the former are more permissive than the latter. ${ }^{5}$ An obvious example is the idea-affirmed in the laws of war, mainstream modern just war theory, and in folk judgments about war - that soldiers do not act wrongly by killing in war (provided that they target only combatants), even if the wars in which they fight are unjust. In other contexts, a norm like this would be highly counterintuitive, since the permissibility of violence usually depends on the permissibility of its end.

The idea that there is a "moral gap" between the norms of war and of private life is also present in classical just war theory, despite it not endorsing the modern position that individuals may permissibly fight in unjust wars. ${ }^{6}$ This is because classical theorists generally took a much more restrictive view of permissible homicide within the private sphere, including self-defensive killing, than is usually accepted today. ${ }^{7}$ In order to square these restrictions with a commitment to the permissibility of fighting in just wars, it remains necessary to treat action in war as governed by more permissive norms.

War ethicists that endorse this disparity are subject to two important and closely related requirements. First, they need to provide a way of clearly demarcating the activities in which the additional permissions apply. Second, they need to give an account of the source of these permissions. On the alternative interpretation that I propose here, the role of the authority criterion is to provide a strategy for satisfying these requirements. The basic idea is that the permissions apply only within conflicts that are fought by a particular kind of entity, and that they obtain in virtue of such conflicts being fought by that type of entity. ${ }^{8}$

In summary, we can understand war-making authority in at least two different ways, in terms of distinct claims about what morally follows from having or lacking that status. But, of course, this leaves open whether any of these claims are true. Are there any properties 
whose possession or absence in fact triggers these normative consequences? As we shall see, many contemporary just war theorists think the answer is no.

\section{SKEPTICISM ABOUT AUTHORITY}

Much of the recent resurgence of interest in the ethics of war has been spurred by the development of an influential reductivist approach, defended most prominently by Jeff McMahan, Cécile Fabre, and Helen Frowe. ${ }^{9}$ Reductivism has been subject to much discussion, but here I focus on one specific aspect: that it generates powerful objections to the authority criterion, on both its permissive and restrictive interpretations.

\section{Reductivism: A Brief Overview}

While there are important disagreements within reductivism, the view can be characterized in terms of a commitment to two core theses. ${ }^{10}$ The first, and most fundamental, is that war is morally continuous with all other domains and governed by precisely the same moral norms. The only morally significant difference between war and ordinary violence between individuals is that the former takes place on a larger and more complex scale. As Jonathan Glover puts it,

It is widely held that killing in war is quite different. It is not, and we need to think about the implications of this ... [A]part from important special side-effects, killing in war is morally on a par with other killing. Declarations of war, military uniforms, and solemn utterances by national leaders in no way reduce the burden of justification for an act of killing. ${ }^{11}$ 
For reductivists, both the resort to war and conduct within war, when justified, are justified precisely because, and to the extent that, they are justified under the same moral principles that justify killing and maiming in all other circumstances. Term this the continuity thesis.

While central to this view, the continuity thesis is entirely formal. It simply holds that the justifications for causing harm by means of war are identical with those contained in ordinary private morality, but does not take a stand on what comprises these justifications. In adding substance, reductivists typically invoke two familiar forms of justification, each of which aims to show how killing can be permissible despite individuals possessing stringent rights against being killed.

The first type of justification appeals to principles of permissible killing in selfdefense. The basic idea is that, under certain conditions, individuals can lose their normal right not to be killed by acting in certain ways (by posing or contributing to threats of serious unjust harm, for example). Such individuals are liable to defensive killing and suffer no rights infringement by being killed in defense of those whom they threaten (subject to additional requirements of proportionality and necessity). On a reductivist view, considerations of liability form the primary justification for killing combatants in war.

Of course, wars typically involve harming individuals who are not liable; innocent noncombatants most obviously. For reductivists, such killing, when justified, is justified by appeal to the lesser evil. According to this justification, an individual's right not to be harmed or killed may, under certain circumstances, be justifiably overridden if doing so is necessary to prevent much greater harms to others. For example, if a war will collaterally kill innocent civilians, but will prevent a far greater number of innocents from being killed in genocide, then those collateral deaths may be justified as the lesser evil.

To conclude, from a reductivist perspective, war is to be morally evaluated in terms of whether the individual actions that constitute it can be justified in terms of aggregated 
liability and lesser evil justifications. As Seth Lazar writes, on this view "justified warfare ... is no more than the coextension of multiple acts justified under these two principles." 12 Term this the content thesis.

\section{Against the Restrictive Authority Criterion}

Objections to the restrictive authority criterion often proceed by disputing specific conceptions of the relevant properties that a belligerent must putatively possess in order to justly resort to war. For example, against the claim that statehood is necessary for legitimate authority, the objector points to wars (real or hypothetical) that seem intuitively justified but are not fought by a state. These objections can be read as disputes about who qualifies as an authority, while still accepting the restrictive criterion that being an authority is a necessary condition of just war. The reductivist approach, by contrast, directly denies this more fundamental claim.

The objection is based on the central reductivist claim that war should be morally analyzed in terms of the aggregation of individuals' permissions to use force on the basis of defensive liability and lesser evil. The key claim is that these ordinary aspects of interpersonal morality are sufficient to justify both the resort to war and the individual acts of killing and injuring necessary for its prosecution. We can move from individual acts of justified defense to a state of justified war by aggregating actions that are each independently justified on the basis of these two principles. ${ }^{13}$ Crucially, these principles (as usually understood) contain no requirement that defense be authorized or carried out by a particular kind of entity. When these justifications obtain, any appropriately motivated and capable agent may act on them. Moreover, individual rights of self-defense are standardly taken to be pre-institutional or "natural" rights that we possess simply in virtue of being persons, ${ }^{14}$ and that other agents (including the state) lack the moral power to deprive us of. ${ }^{15}$ 
From this, reductivists draw the conclusion that "it is not a necessary condition of just or justified war that it be initiated only by persons who are properly authorized to do so.",16 The right to wage war is ultimately an individual right; and since anyone may potentially use force in self-defense (and in defense of others), permissible warfare cannot be necessarily restricted to a certain class of entities. As Cécile Fabre puts it, "Groups of actors which act in unstructured, disorganized ways, as well as individuals themselves, can have the right to go to war." ${ }^{\prime 17}$ On this view, the authority requirement is (at best) morally redundant and ought to be jettisoned.

To clarify, reductivists do not claim (implausibly) that whether a belligerent entity has certain properties - such as size, political organization, or possession of territory-is irrelevant to whether it may resort to war. The claim is that such properties are not an independent requirement of just war. This is compatible with these properties having derivative importance, in terms of affecting whether a belligerent satisfies other ad bellum criteria - such as reasonable prospect of success - that can be accounted for in wholly reductive terms.

\section{Against the Permissive Authority Criterion}

Though critics tend to focus on the standard, restrictive interpretation of the authority criterion, reductivism also rejects the permissive interpretation. Recall that on this interpretation the criterion grounds the idea that individuals in war are subject to more permissive norms of violent conduct. As discussed earlier, under the continuity thesis, reductivists deny, contra both mainstream just war theory and the classical just war tradition, that there is any moral gap between war and ordinary life. Against the mainstream view, they close the gap by rejecting conceptions of jus in bello that conflict with ordinary interpersonal morality (such as the permission to fight in unjust wars). ${ }^{18}$ In the case of the classical view, 
by contrast, they close the gap by rejecting the restrictive conception of permissible harm between private individuals. By rejecting moral gaps, reductivism removes the need to posit the permissive authority criterion, since there is no need to distinguish war from nonwar, nor to explain where any new permissions come from.

While a commitment to the continuity thesis thus undercuts one important source of support for the criterion, it is not sufficient to warrant jettisoning it entirely. The thesis simply holds that war is governed by the same moral principles that apply in all other contexts. This leaves open the possibility that this unified set of principles grants additional permissions to cause harm to individuals who do so on behalf of certain kinds of entities, both within and outside the context of war.

The reductivist content thesis, however, closes off such a view. According to this thesis, considerations of defensive liability and lesser evil exhaust the justifications for nonconsensual killing. If an individual (i) has a right not to be killed and (ii) her death is not necessary to achieve a very great good, then killing her in war is morally unjustified. As McMahan puts it, "On [a reductivist] view, the limits of individual self- and other-defense are also the limits of national defense."19 If correct, the normative consequence encapsulated in the permissive authority criterion cannot be triggered: the fact that one uses violence on behalf of a particular kind of group or organization cannot extend one's permissions to cause serious harm to others. ${ }^{20}$

In summary, reductivists reject the restrictive authority criterion because they hold that ordinary principles of individual self-defense and lesser evil are sufficient to justify waging war. Conversely, they reject the permissive criterion because they take those very same principles to be necessary to justify waging war. Whereas the restrictive criterion wrongly denies individuals' rights to defense, the permissive criterion fails to acknowledge the stringency of individuals' rights not to be killed and maimed. 


\section{Defending the Restrictive Authority Criterion}

In this section and the next I consider the prospects for rehabilitating the authority criterion. Of course, one tactic would be to reject reductivism wholesale. But I find reductivists' focus on basic human rights very appealing. If reductivists are correct that there is a deep tension between this commitment and the claims of the authority criterion, then it is unclear to me why we would want to maintain the latter at the expense of the former. Instead of rejection, I am interested in exploring an alternative strategy that aims to show that the authority criterion can be rendered compatible with a broadly reductivist outlook. On this approach, we can give a (qualified) defense of the criterion from within a view that treats the morality of war as derived solely from principles governing permissible defense between individuals. I start with the restrictive version of the criterion.

As explained above, reductivists reject this criterion due to a sufficiency claim: If all of a war's harms can be justified in terms of defensive liability and lesser evil, then waging that war is morally permissible. To defend the criterion, it needs to be shown that liability and lesser evil are not enough; some further fact about the belligerent agent is required for justification. Furthermore, to make this compatible with the basic commitments of reductivism, this further fact needs to be located within the morality of individual defense.

One promising proposal, suggested by several theorists, appeals to the notion of consent or authorization. ${ }^{21}$ The claim here is that an independent and necessary condition of justified defensive harm is that one have the consent of those on whose behalf it is employed (or, at very least, that they do not overtly refuse). This consent requirement, as I will call it, gains intuitive support from judgments about simple cases of individual defense. For example, if Angela unjustly attacks Vicky, and Vicky competently refuses Rachel's defensive 
assistance, it seems wrong for Rachel to defend Vicky against her will. Victims occupy a privileged position within the morality of defense - it is their interests at stake after all—and this gives them the exclusive right to decide whether and how those interests are defended. ${ }^{22}$ The consent requirement thus tracks an important distinction between there merely being a potential justification for defensive harm (such as the attacker's liability) and a particular agent having the standing to act on that justification. For the latter, the will of the victim must be engaged.

This undertheorized aspect of the morality of defensive harm enables a possible defense of the restrictive authority criterion. On this view, having the authority to wage war consists in being authorized to do so by those on whose behalf the war is fought. Without this authorization waging war is impermissible, even if all its constitutive harms can be justified in terms of defensive liability and lesser evil. So interpreted, the reductivist critique rests on a mistakenly narrow account of the conditions of permissible individual defense. Since these criteria do contain an analogue of the authority criterion, it does not follow from the fact that these conditions are sufficient to justify war that the authority criterion must be jettisoned.

While I am sympathetic to rehabilitating the authority criterion in terms of consent, I think there are at least two important complications for this idea. These do not challenge the general claim that consent or authorization is necessary for justified war. Rather, they question precisely what counts as satisfying the requirement. The challenge arises due to an obvious disanalogy between war and small-scale defense cases (in which the consent requirement seems most plausible.) While the latter involve a handful of individuals, war typically involves large groups. This makes the application of the consent requirement to war far from obvious, since there is no straightforward sense in which a group can univocally consent to or refuse defense in the same way that a single victim can. Moreover, among any large group it is unlikely that the preferences of all members will be unanimous. The 
requirement thus needs to be refined if it is to tell us what counts as an overall "yes" or "no" in these cases. More precisely, what we need is an aggregation principle, which tells us how we should move from the consent and refusal of individual group members to a conclusion about whether or not the consent requirement has been satisfied. Providing such a principle is difficult, and yet without one our revised authority criterion will be incapable of giving any determinate verdicts.

\section{The Demos Problem}

One intuitive suggestion — familiar from debates over humanitarian intervention — is to adopt a majoritarian aggregation principle for the consent requirement. On this view, in order for military intervention to be justified, a majority (or perhaps a supermajority) of those subject to intervention must consent to it (or at least not overtly reject it). Since majority rule is considered the morally optimal means of decision-making in many other contexts, this seems appealing. However, cases of war and intervention raise problems for the majoritarian proposal. (Since this proposal is most commonly discussed in the specific context of humanitarian intervention, I will continue to use the example of intervention to demonstrate some of its complications. But I think similar worries arise, mutatis mutandis, for other forms of war.)

The first problem concerns the question of whose preferences should be counted for the purpose of justifying the use of military force. This is an instance of a more general problem in democratic theory, known as the "demos" or "boundary" problem. ${ }^{23}$ The problem is that while we may agree that certain matters should be decided by a collective decision procedure - such as majority rule - this does not tell us anything about who should be included in the procedure. This is important because the decision about who to include can significantly affect the verdict that the procedure yields. 
To illustrate the problem, imagine we have to decide whether to introduce a new rule for U.K. professional football that caps player salaries. Let us also imagine we want to decide this matter by a majority vote and that there are three ways we could go about doing so. First, we could restrict the vote to fans of the richest teams, such as Manchester United and Chelsea, who will be most disadvantaged by the rule change. If we adopt this method, a majority will likely vote against the new rule. Second, we could include the fans of all football teams. If we do so, a majority will likely vote in favor of the salary cap. Third, we could broaden the franchise even further to include all British citizens. This will likely yield a majority vote against the proposal (let us assume the British public generally wants to attract the best players to their league.) As this example illustrates, we get different results depending on how we specify the scope of the majoritarian procedure. The crucial question, then, is how to determine whose preferences are relevant? This problem has important implications for the case of war and intervention: If majority consent is required in order to permissibly use military force, among what set of persons should we look for this majority?

One obvious response is to say that all citizens of a country subject to intervention should get a say. For example, if France is considering intervention against the Assad regime in Syria, this would only be permissible if the majority of Syrians desire it. However, on reflection this seems too broad, since it would include the preferences of those perpetrating the injustices that the intervention seeks to remedy. This implies that intervention would be impermissible in cases where a majority ethnic group within a state is oppressing a minority group, since the majority of the state's citizens would refuse intervention. This is highly counterintuitive. Wrongdoers presumably do not get a say in whether their crimes are prevented. $^{24}$

Alternatively, we could take a more restrictive view, according to which only members of the victim group get a say. This avoids the above problem, since it excludes 
wrongdoers. It also excludes individuals who are neither wrongdoers nor victims, but simply bystanders. This additional restriction seems plausible in certain cases. For example, imagine that the Welsh start to violently oppress the Scots, and that France is weighing an intervention in Scotland to protect its inhabitants (let us assume the British government is unable to do so). It is not obvious here that $m y$ preferences, as an English person, are relevant to whether the French may protect the Scots, despite my being a citizen of the state subject to intervention. Moreover, if the preferences of the English are included, this implies that it would be wrong for France to intervene on behalf of the Scots if a majority of the English refuse, even if all the Scots desire it, since the English make up the vast majority of citizens of the United Kingdom. Again, this seems counterintuitive.

We should not, however, be too quick to exclude bystanders. While bystanders may be uninvolved in the injustices that intervention seeks to remedy (either as victims or perpetrators), this does not mean they would be uninvolved if an intervention were to occur. The negative consequences of intervention often extend beyond the borders of the target state. ${ }^{25}$ There are risks of collateral harm and the potential impact of refugee flows, for example. If inclusion within the decision procedure is determined by whether one may be negatively affected by an intervention, these risks indicate that even bystanders who are not members of the country or region subject to intervention should also be represented.

The preferences of one additional group also seem relevant: those individuals whose resources will be used to fund a war or intervention. The use of military force is extremely costly, and we usually think that citizens are entitled to a strong say over what their state does with the resources that they have contributed. The question is how much of a say? One important factor here concerns whether citizens have enforceable moral duties to contribute resources for certain uses of military force, such as interventions to protect foreigners from serious injustices or military aid to nations facing aggression. ${ }^{26}$ If they do, then this may place 
limits on their right to control what is done with their resources, since we do not generally have discretion over whether to fulfill our duties. ${ }^{27}$ For example, one might argue that from 1941 to 1945 , U.S. citizens were under an enforceable moral duty to contribute via taxation to Roosevelt's Lend-Lease program, which provided military aid to the Allies. If so, that program may have been justifiable independently of whether U.S. citizens supported it.

As we can see, identifying the group of persons whose consent is relevant to justifying the use of force is far from straightforward. An additional complication is also worth mentioning. This concerns whether we should count the preferences of all relevant individuals equally, or whether we should give them different weightings. For example, should the wishes of affected bystanders have the same standing as the preferences of victims, or do certain groups have priority over others? Even within groups, should we treat all members' preferences equally? Or should we weigh them in proportion to how greatly they would be affected by the use of force? ${ }^{28}$ These are important questions, but also dauntingly difficult. Nevertheless, they require answers if the consent-based rehabilitation of the authority criterion is to have any determinate content. ${ }^{29}$

\section{The Aggregation Problem}

The demos problem arises because a majoritarian interpretation of the consent requirement is open to multiple interpretations. But should we accept the majoritarian assumption in the first place? As several theorists have noted, judgments about cases of individual defense put pressure on this idea. Consider the following example: Ten members of a religious group have been kidnapped and are being tortured by their captors. Luckily, Rachael is nearby and can shoot the kidnappers with her sniper rifle, thereby rescuing all the victims. However, while two members of the victim group desire rescue, the remaining eight victims competently refuse Rachael's intervention because they are deeply committed to 
nonviolence. ${ }^{30}$ Here a (super)majority of victims refuse defense, yet it seems clearly permissible (at least to me) for Rachael to intervene nonetheless.

Cases like this suggest that there is an important moral limit to majority rule. While individuals may have the right to decide whether or not their own lives are defended, this does not extend to the lives of others. As Andrew Altman and Christopher Heath Wellman put it, "It seems dubious to hold that a group has this type of normative dominion over its members." 31 This challenges the consent-based defense of the authority criterion. Though justified defense may include a consent requirement, when applied to the case of war and intervention it turns out to be so weak as to be trivial: as long as any member of the victim group consents, it looks like the requirement is met.

Critics of consent-based constraints on war often take examples like the one above to be decisive. But defenders of the authority criterion may yet have the resources to respond. To argue for a more robust consent-based constraint on war, we need to show two things. First, we need to identify some relevant differences between defensive wars or interventions, on the one hand, and cases like the kidnappers example, on the other. Second, we need to explain why these differences amplify a demand for consent or authorization. To this end, here are three suggestions.

First, military action does not often aim simply at defending lives and limbs, but also the kinds of goods protected by collective rights, such as territory, self-determination, and political independence. When such goods are the object of defense (unlike in the kidnappers case), it does not seem implausible that a collective authorization procedure-such as majority vote - is morally appropriate. If so, a more robust consent requirement may apply to an important subset of defensive practices.

Second, wars and interventions typically do not restrict harms to wrongdoers, but also impose serious risks on their intended beneficiaries. Other things being equal, the 
permissibility of imposing harms on persons should be sensitive to whether those persons endorse the ends for which the harms will be imposed.

Third, victim preferences might not only be relevant to whether imposing costs on victims is morally justified, but also on whether collaterally harming bystanders is permissible. In order to justify harming bystanders, a defender must appeal to the good of those who will benefit from doing so. It seems plausible that to the extent that the prospective beneficiaries (the victims themselves) reject being benefitted in this way, the harder it is to successfully invoke that justification for harming bystanders. ${ }^{32}$

This is just a snapshot of how one might go about rehabilitating the authority criterion by leveraging intuitions about the importance of consent in individual defense cases. While I am sympathetic to that project, it is clear that far more work needs to be done. The precise shape of the consent requirement on defensive force likely depends on a range of interacting factors, each requiring detailed investigation.

\section{Defending the Permissive Authority Criterion}

Recall that on this interpretation, the normative consequence of having war-making authority is that one's agents thereby enjoy more extensive permissions to cause harm. As reductivists point out, the question is how this could possibly be justified. How can killings and maiming that would otherwise be straightforwardly morally wrong (in virtue of lacking a defensive liability or lesser evil justification) somehow become permissible in virtue of being carried out on behalf of a particular sort of entity?

I believe a highly qualified defense of the permissive criterion is at least possible and worth exploring, and that this defense is broadly compatible with reductivism. My preferred strategy invokes the idea of legitimate authority as debated within political and legal 
philosophy. On this conception, to have legitimate authority is to possess the morally justified power to issue commands and, by doing so, to place those commanded under an obligation to obey. ${ }^{33}$ The proposal to be considered holds that agents subject to (a very specific kind) of authority can be morally required, all things considered, to obey commands to cause harm in war. Importantly, this will include cases in which causing harm would not be morally permissible in the absence of the command. ${ }^{34}$

At this point an obvious objection presents itself. The obligation to obey is neither unconditional nor absolute. Wherever the precise limits of the duty lie, surely commands to cause serious harm in the absence of a preexisting justification exceed them. Such commands are either invalid, creating no obligation to obey, or the obligation is overridden by the subject's weightier duty to refrain from harming. As Matthew Noah Smith puts it,

The first characteristic of the obligation to obey the law is that there are very few limits on what an obligation to obey the law can require a subject to do. There are, of course, some limits. Presumably, if obedience to the law requires commission of serious moral wrongs, then one is not obligated to obey the law. But this limit is at the moral extremes. $^{35}$

This objection seems very plausible. Consider several standard justifications of the duty to obey, such as those grounded in consent or promise, gratitude, fair play, reciprocity, or respect for democratic decision-making. On all these views, it seems obvious (at least to me) that when the duty to obey conflicts with the duty not to kill or injure, the former duty is overruled. Nonetheless, I believe a defense of the permissive authority criterion remains possible by appeal to "functionalist" justifications of authority. On this family of views, authorities possess the moral power to impose obligations on subjects in virtue of performing some important task. The scope and limits of this power are calibrated to what is required for 
the authority to perform the legitimating function. I believe that a highly specific account of the relevant function, which draws on Joseph Raz's influential "service conception" of authority ${ }^{36}$ has the resources to explain how commands to cause serious harm can create undefeated obligations to obey, including in cases where harming would otherwise be morally unjustified - in other words, where a defensive liability or lesser evil justification is lacking. ${ }^{37}$

Service-based justifications of authority advance two main theses. The first specifies what having authority consists of in terms of a hierarchical account of practical reasons. On this view, an authoritative command to take a certain action is intended to give its subject both an additional first-order reason for taking that action and a second-order exclusionary reason not to act on the basis of (some of) the preexisting first-order reasons related to that action. Rather than being outweighed, those reasons are replaced or "preempted" by the command, and no longer bear on how the subject ought to act.

The second thesis provides an account of how the power to create preemptive obligations can be justified. On this view, authority is justified in virtue of the rational service it provides its subject. Authorities are entitled to create new obligations because, and to the extent that, their having this ability enables their subjects to better achieve the aims that they have reason to achieve independently. As Raz formulates this idea,

The normal way to establish that a person has authority over another person involves showing that the alleged subject is likely better to comply with reasons which apply to him ... if he accepts the directives of the alleged authority as authoritatively binding and tries to follow them, rather than by trying to follow the reasons which apply to him directly. ${ }^{38}$ 
Authorities can serve their subject in two main ways. First, obeying a common authority can enable individuals to better coordinate their behavior with one another, thus enabling them to resolve various collective action problems. Second, an authority may possess greater expertise than the subject on certain important matters. In each case, subjects better conform to reason by treating the authority's directives as preemptively binding within a certain domain, rather than by acting on their own assessment of the relevant considerations directly. Importantly, a service-based view accounts for a central feature of the obligation to obey: the obligation can be decisive even in (at least some) cases where the command fails to reflect the balance of independent reasons. This is because authorities do not need to be infallible in order to successfully serve their subjects. As long as an authority's commands more reliably track right reason than the judgments of the subject, the subject still optimizes his overall conformity with reason by obeying the authority-including in certain cases where the authority errs - compared to acting on his own assessment. However, this does not mean that all commands that fail to track right reason generate obligations to obey, even when issued by a legitimate authority. Considerations of service justify obedience only to the extent necessary to improve conformity with reason. Obedience beyond this point is irrational. The cases in which mistaken commands remain binding are those in which identifying the mistake would require the subject to engage in the same process of reasoning that the authority went through in issuing its command. These commands remain binding because a policy of second-guessing the authority in this way requires forsaking the benefits of obedience (since the point of obedience is to compensate for one's deficiencies with respect to that process). ${ }^{39}$ However, when identifying a mistaken command does not incur this rational cost, the command creates no obligation to obey and the subject is free to disregard it (indeed, they are required to do so). These will be cases in which the mistake is "clear," such that the subject can identify it directly without repeating the authority's 
reasoning. For example, if the command is inconsistent with any plausible interpretation of the known facts, or if the subject has good evidence that the authority is incompetent, lying, or otherwise procedurally compromised, then she is under no service-based duty to obey in that particular case. What unifies all these cases is that disobedience is compatible with optimizing one's conformity with reason. So, while service accounts give authorities considerable moral power to create obligations, the scope of this power is subject to principled limits.

Service-based accounts provide a very general model of legitimate authority-A has authority over B within domain X, if obeying A's commands enables B to conform better to the X-related reasons that apply to B. The argument from this general strategy to a qualified defense of the permissive just war authority criterion proceeds in five steps.

The first is to make one element more specific: the domain within which authority may be possessed. Presumably, unless extreme pacifism is true, there are possible domains in which acting in accordance with reason may involve causing serious harm to others. Term such domains harm-apt.

The second points out that agents operating in harm-apt domains may be differently situated regarding their abilities to (i) assess and act on the reasons that govern the distribution of harm and (ii) to coordinate with one another. Term this agent-variability.

The third step combines the first two: given harm-aptness and agent-variability, agents may better conform with the reasons that govern the distribution of harm by generally obeying the commands of another, rather than by acting on their own assessment on a caseby-case basis. On a service-based view, this establishes how one agent may acquire authority over another regarding the distribution of harm. If an agent's optimal means of distributing harm is by obeying the commands of an authority, it seems uncontroversial that this is what they are morally required to do. 
To derive the conclusion that subjects may be required to obey commands to cause harms that would otherwise be morally unjustified, a fourth step is required. This is provided by the fact that, as explained above, legitimate authority does not require infallibility. Obeying an authority across a range of cases can still be the optimal overall means of conforming to reason, even if a subset of its commands fail to track right reason. Applying this general idea to the specific case of authorities that are legitimate with respect to harm-apt domains, it follows that mistaken-yet-binding commands may include those that require subjects to distribute harm in ways that are not supported by authority-independent justifications (such as liability or lesser evil).

A fifth and final step repeats the first, by further specifying the domain of authority. For our purposes, we are interested in one particular harm-apt domain - that of the reasons that govern the distribution of harm by means of war.

With this specification in place, we have the materials for a highly qualified defense of the permissive authority criterion. On this account, A has authority over B regarding the domain of warfare if, by obeying A's commands, B achieves greater overall conformity with the reasons that govern the distribution of harm by means of war, compared to not obeying. When these conditions are met, the authority's commands are capable of placing their subject under an undefeated obligation to cause harm in war, including in (at least some) cases in which those commands fail to reflect right reason, and require causing harms that are not justified on the basis of liability or lesser evil. Contra reductivism, it is not a necessary condition of permissible harm in war that it be justified in one of these two ways.

Perhaps the most salient implication of this account is that authoritative commands could justify an agent participating in a war that is ad bellum unjustified. If subjects will likely do better in terms of distributing harms by obeying an authority - their government, most obviously_on matters of jus ad bellum (or some important subset of jus ad bellum), 
then they may be all-things-considered required to obey commands to fight in an unjustified war. But it is important to note that the argument does not require justifying this particular normative consequence. Provided an authority serves its subjects with respect to some range of considerations that are relevant to the permissibility of harming in war, it will possess the power to issue undefeated commands to cause otherwise-unjustified harm in war (even if it does not possess the power to command participation in unjust wars). The precise scope of this power will depend on the particular war-related service provided.

Though the account sketched above denies reductivist objections to the permissive authority criterion, I believe it is broadly compatible with the core commitments of reductivism. First, in line with the reductivist continuity thesis, it denies that war is in any sense morally sui generis. Rather, it defends the criterion by applying a general account of how one individual's authority over another can be justified to the particular domain of warfare, and argues that if we accept such an account of legitimacy in the more mundane domains in which authority is usually discussed, then there is no principled basis for denying that subjects may have undefeated duties to cause harms in war that would otherwise be morally unjustified.

Second, the account is consistent with the individualistic and aggregative approach to the ethics of warfare endorsed by reductivists. On a service-based account, authority claims are evaluated solely on the basis of the relationship between the authority and each individual over whom it claims the power to impose obligations. The extent of an authority's legitimacy is simply the sum of its authority over individuals. ${ }^{40}$

Third, while the account denies the reductivist content thesis-which holds that considerations of liability and lesser evil exhaust the justifications for harming in war-the thesis may still play an important justificatory role. On a service-based view, authorities are justified in virtue of their ability to enable subjects to better conform to reasons that apply to 
them independently. This is compatible with the content thesis providing an exhaustive account of the authority-independent justifications that govern warfare. So, while the view I have sketched denies that liability and lesser evil are the sole justifications for harm in war, it can accept the view that all such justifications are ultimately, if indirectly, grounded in those two considerations.

To conclude, let me highlight two sorts of objections that can be made against the permissive authority criterion. The first, which my proposal responds to, is the claim that acting at the behest of a certain type of entity cannot in principle increase an individual's permissions to cause harm. To use the terminology I introduced at the beginning of this article, the objector holds that there are no properties capable of triggering this normative consequence. Though intuitive, I have suggested that this position may not be compatible with plausible views about the justification of authority more generally. But this leaves open the question of whether particular belligerent entities in fact possess the relevant authoritygenerating properties. This enables a second form of objection, which denies that these properties are ever instantiated. Determining this will be a matter of empirical investigation, but I think it is safe to say that the properties I have identified are fairly demanding, and that many states —including generally legitimate states — will fail to satisfy them with respect to the whole domain of war-related activity. This is in line with the common view in contemporary political philosophy that states typically lack the authority they claim for themselves, ${ }^{41}$ and the account that I have offered is certainly not intended as an apology for state practice. If states (or other political entities) typically fail to serve their subjects in the manner required for war-making authority, then so much the worse for state authority. However, since my proposal is open to authority being possessed with respect to certain aspects of warfare and not others, the conditions for possessing the relevant kind of authority may be less demanding than we might initially think. 


\section{NOTES}

${ }^{1}$ See Frederick Russell, The Just War in the Middle Ages (Cambridge: Cambridge University Press,
1977); and Heather Wilson, International Law and the Use of Force by National Liberation
Movements (Oxford: Oxford University Press, 1988), ch. 1.
${ }^{2}$ For a detailed list of references, see my "Civil War and Revolution," in Helen Frowe and Seth Lazar,
eds., The Oxford Handbook of Ethics of War (Oxford: Oxford University Press, forthcoming). In
addition, see Cécile Fabre, "Cosmopolitanism, Just War Theory and Legitimate Authority," International Affairs 84, no. 5 (2008), pp. 963-76; Yitzhak Benbaji, "Legitimate Authority in War," in Frowe and Lazar, Oxford Handbook of Ethics of War; Magnus Reitberger, "License to Kill: Is Legitimate Authority a Requirement for Just War?” International Theory 5, no. 1 (2013), pp. 64-93; Eric A. Heinze and Brent J. Steele, eds., Ethics, Authority, and War (New York: Palgrave Macmillan, 2009); Anthony F. Lang Jr., Cian O’Driscoll, and John Williams, eds., Just War: Authority, Tradition, and Practice (Washington, D.C.: Georgetown University Press, 2013); Robert Blair and Pablo Kalmanovitz, "On the Rights of Warlords: Legitimate Authority and Basic Protection in War-Torn Societies," American Political Science Review 110, no. 3 (2016), pp. 428-40; Anna Stilz, "Authority, Self-Determination, and Community in Cosmopolitan War," Law and Philosophy 33, no. 3 (2014) pp. 309-35; Uwe Steinhoff, On the Ethics of War and Terrorism (New York: Oxford University Press, 2007), ch. 1; and Christopher Kutz, On War and Democracy (Princeton: Princeton University Press, 2016), ch. 3 .

${ }^{3}$ I defend these claims in much more detail in Jonathan Parry, "Just War Theory, Legitimate Authority, and Irregular Belligerency," Philosophia 43, no. 1 (2015), pp. 175-96. In his contribution to this symposium, Pål Wrange argues that, as a matter of international law, the notion of authority in war may in fact be much more diverse than I have suggested.

${ }^{4}$ For similar interpretations, see Cécile Fabre, Cosmopolitan War (Oxford: Oxford University Press, 2012), p. 160; Christopher Finlay "Legitimacy and Non-State Political Violence," Journal of Political Philosophy 18, no. 3 (2010), pp. 287-312; and Reitberger, "License to Kill." See also A. J. Coates, The Ethics of War (Manchester: Manchester University Press, 1997), ch. 5.

${ }^{5}$ For a recent endorsement, see Daniel Brunstetter, “Jus ad Vim: A Rejoinder to Helen Frowe," Ethics \& International Affairs 30, no. 1 (2016), pp. 131-36.

${ }^{6}$ See Gregory M. Reichberg, "The Moral Equality of Combatants - A Doctrine in Classical Just War Theory? A Response to Graham Parsons," Journal of Military Ethics 12, no. 2 (2013), pp. 181-94.

${ }^{7}$ As George Fletcher points out, "Until the Statute of Henry VIII, passed in 1532 . . . there was no theory of self-defense that rendered a killing fully lawful, justifiable and therefore free of the taint that 
affected excusable homicide." George Fletcher, "Defensive Force as an Act of Rescue," Social Philosophy and Policy 7, no. 2 (1990), p. 171.

${ }^{8}$ For discussion, see, Kutz, On War and Democracy, ch. 3.

${ }^{9}$ Jeff McMahan, Killing in War (New York: Oxford University Press, 2009); Fabre, Cosmopolitan War; and Helen Frowe, Defensive Killing (New York: Oxford University Press, 2014). See also Kai Draper, War and Individual Rights (New York: Oxford University Press, 2016).

${ }^{10}$ Here I draw on Seth Lazar, "National Defence, Self-Defence, and the Problem of Political Aggression," in Cécile Fabre and Seth Lazar, eds., The Morality of Defensive War (New York: Oxford University Press, 2014), pp. 11-39.

${ }^{11}$ Jonathan Glover, Causing Death and Saving Lives (London: Penguin, 1977), pp. 251-52. For an analogue of the continuity thesis applied to the use of force by state officials outside the context of war, see John Gardner, "Criminals in Uniform," in Anthony Duff, Lindsay Farmer, Sandra Marshall, Massimo Renzo, and Victor Tadros, eds., The Constitution of the Criminal Law (Oxford: Oxford University Press, 2013), pp. 97-118.

${ }^{12}$ Lazar, "National Defence, Self-Defence, and the Problem of Political Aggression," p. 12.

${ }^{13}$ See Jeff McMahan, "War as Self-Defense,” Ethics \& International Affairs 18, no. 1 (2004), pp. 75 80.

${ }^{14}$ See James W. Nickel, "Griffin on Human Rights to Liberty," in Roger Crisp, ed., Griffin on Human Rights (New York: Oxford University Press, 2014), p. 200.

${ }^{15}$ See Kimberly Ferzan, "Self-Defense and the State," Ohio State Journal of Criminal Law 5, no. 2 (2008), pp. 449-504.

16 Jeff McMahan, "Just War," in Robert E. Goodin, Philip Pettit, and Thomas Pogge, eds., $A$ Companion to Contemporary Political Philosophy, $2^{\text {nd }}$ Edition (Oxford: Blackwell, 2007), p. 671. For further reductivist rejections of the restrictive authority criterion, see Fabre, Cosmopolitan War, chs. 3-4; Jeff McMahan, “Just Cause for War," Ethics \& International Affairs 19, no. 3 (2005), pp. 1-21, especially p. 4; and Steinhoff, On the Ethics of War and Terrorism, ch. 1.

${ }^{17}$ Fabre, Cosmopolitan War, pp. 144-45. See also Steinhoff, On the Ethics of War and Terrorism, p. 20; Uwe Steinhoff, "What is War?-And Can a Lone Individual Wage One?" International Journal of Applied Philosophy 23, no. 1 (2009), pp. 133-50; and James Pattison, "When Is It Right to Fight? Just War Theory and the Individual-Centric Approach," Ethical Theory and Moral Practice 16, no. 1 (2013), pp. 34-54, especially p. 53.

${ }^{18}$ See McMahan, Killing in War.

19 Jeff McMahan, "War," in David Estlund, ed., The Oxford Handbook of Political Philosophy (Oxford: Oxford University Press, 2012), 298-315, at p. 310 (my emphasis).

${ }^{20}$ In a talk given at Stockholm University in May 2014, McMahan explicitly labeled this view the "No Extensions Principle." 
${ }^{21}$ Finlay, "Legitimacy and Non-State Political Violence"; Christopher Finlay, Terrorism and the Right to Resist (Cambridge: Cambridge University Press, 2015); Anne Schwenkenbecher, "Rethinking Legitimate Authority," in Fritz Allhoff, Nicholas G. Evans, and Adam Henschke, eds., Routledge Handbook of Ethics and War (Abingdon: Routledge, 2013), pp. 161-70; Seth Lazar, “Authorisation and the Morality of War," Australasian Journal of Philosophy 94, no. 2 (2016), pp. 211-26. See also Lionel K. McPherson, “Is Terrorism Distinctively Wrong?” Ethics 117, no. 3 (2007), pp. 524-46.

${ }^{22}$ For more detailed discussion, see Cécile Fabre, "Permissible Rescue Killings," Proceedings of the Aristotelian Society 109 (2009), pp. 149-64; Finlay, "Legitimacy and Non-State Political Violence."

${ }^{23}$ See Robert E. Goodin, "Enfranchising All Affected Interests, and its Alternatives," Philosophy \& Public Affairs 35, no. 1 (2007), pp. 40-68.

${ }^{24}$ See Fernando Tesón, "The Liberal Case for Humanitarian Intervention," in J. L. Holzgrefe and Robert O. Keohane, eds., Humanitarian Intervention: Ethical, Legal, and Political Dilemmas (Cambridge: Cambridge University Press, 2003), pp. 93-130.

${ }^{25}$ James Pattison, "Representativeness and Humanitarian Intervention," Journal of Social Philosophy 38 , no. 4 (2007), pp. 569-87.

${ }^{26}$ For further discussion, see Allen Buchanan, "The Internal Legitimacy of Humanitarian Intervention," Journal of Political Philosophy 7, no. 1 (1999), pp. 71-87.

${ }^{27}$ A similar point might also apply to bystanders: If bystanders have a duty to shoulder a certain level of risk, their objections to the use of force may be discounted.

${ }^{28}$ See Harry Brighouse and Marc Fleurbaey, "Democracy and Proportionality," Journal of Political Philosophy 18, no. 32 (2010), pp. 137-55.

${ }^{29}$ For further discussion, see Benbaji, "Legitimate Authority in War."

${ }^{30}$ Based on a case in Andrew Altman and Christopher Heath Wellman, "From Humanitarian Intervention to Assassination: Human Rights and Political Violence," Ethics 118, no. 2 (2008), pp. 228-57, especially p. 244.

${ }^{31}$ Ibid., p. 243.

${ }^{32}$ I explore this particular idea at length in Jonathan Parry, "Consent and the Justification of Defensive Harm" (unpublished manuscript).

${ }^{33}$ See Scott Shapiro, "Authority," in Jules Coleman and Scott Shapiro, eds., The Oxford Handbook of Jurisprudence and Philosophy of Law (New York: Oxford University Press, 2002), pp. 382-439.

${ }^{34}$ The following proposal draws on arguments I defend in much greater detail in Jonathan Parry, "Authority and Harm," in David Sobel, Peter Vallentyne, and Steven Wall, eds., Oxford Studies in Political Philosophy, Vol. 3 (forthcoming). For different arguments for a broadly similar conclusion, see David Estlund, “On Following Orders in an Unjust War," Journal of Political Philosophy 15, no. 2 (2007), pp. 213-34; Cheyney Ryan, "Democratic Duty and the Moral Dilemmas of Soldiers," Ethics 
122, no. 1 (2011), pp. 10-42; and Massimo Renzo, "Duties of Citizenship and Just War" (unpublished manuscript).

${ }^{35}$ Matthew Noah Smith, "Political Obligation and the Self," Philosophy and Phenomenological Research 86, no. 2 (2013), p. 349 (my emphasis).

${ }^{36}$ Joseph Raz, The Morality of Freedom (New York: Clarendon Press, 1986), chs. 1-4; Joseph Raz, Between Authority and Interpretation (New York: Oxford University Press, 2009), ch. 5.

${ }^{37}$ For a different invocation of a Razian conception of authority in the context of war, see Benbaji, "Legitimate Authority in War."

${ }^{38}$ Raz, Morality of Freedom, p. 53.

${ }^{39}$ Raz, Morality of Freedom, pp. 67-69. The preemptive character of commands can also be defended by an argument from double counting. Ibid., pp. 58-59.

${ }^{40}$ Raz, Morality of Freedom, p. 71.

${ }^{41}$ See, for example, Leslie Green, The Authority of the State (Oxford: Oxford University Press, 1988); A. John Simmons, "Political Obligation and Authority," in Robert L. Simon, ed., The Blackwell Guide to Social and Political Philosophy (Oxford: Blackwell Publishers, 2002), pp. 17-37; and Joseph Raz, The Authority of Law: Essays on Law and Morality (Oxford: Oxford University Press, 1979), ch. 12. 